\title{
Public Interest in Cognitive Impairment: An Analysis of the Top 50 Articles on Cognitive Impairment on Altmetric
}

\author{
Yeo Jin Kim $\mathbb{D}^{1},{ }^{1}$ Yerim Kim, ${ }^{2}$ Jee-Eun Kim $\mathbb{D}^{3}{ }^{3}$ Yoo Hwan Kim, ${ }^{4}$ Dae Young Yoon, \\ and Jong Seok Bae $\mathbb{i D}^{2}$ \\ ${ }^{1}$ Department of Neurology, Chuncheon Sacred Heart Hospital, Hallym University College of Medicine, Chuncheon, \\ Republic of Korea \\ ${ }^{2}$ Department of Neurology, Kangdong Sacred Heart Hospital, Hallym University College of Medicine, Seoul, Republic of Korea \\ ${ }^{3}$ Department of Neurology, Seoul Medical Center, Seoul, Republic of Korea \\ ${ }^{4}$ Department of Neurology, Hangang Sacred Heart Hospital, Hallym University College of Medicine, Seoul, Republic of Korea \\ ${ }^{5}$ Department of Radiology, Kangdong Sacred Heart Hospital, Hallym University College of Medicine, Seoul, Republic of Korea
}

Correspondence should be addressed to Jong Seok Bae; lwsbae@naver.com

Received 27 August 2019; Revised 2 January 2020; Accepted 6 January 2020; Published 29 January 2020

Academic Editor: Sang Won Suh

Copyright (C) 2020 Yeo Jin Kim et al. This is an open access article distributed under the Creative Commons Attribution License, which permits unrestricted use, distribution, and reproduction in any medium, provided the original work is properly cited.

Background. As the average life expectancy continues to increase, interest in cognitive impairment is increasing. Nowadays, as social media expands its reach, academic research is spreading through social media, changing the way and speed by which research is propagated and also who consumes this content. Therefore, using Altmetric, a new web-based set of metrics that analyzes the impact of content on social media platforms, we investigated the characteristics of influential research articles on the topic of cognitive impairment in social media. Methods. An Altmetric Explorer search was performed on May 25, 2018, to extract the following information: (i) journal name, (ii) journal impact factor (IF), (iii) year of publication, (iv) article topic, (v) article type, and (vi) cognitive impairment subtype. Results. The journal "Neurology" was the most cited journal for cognitive impairment articles shared on social media. Among the various types of cognitive impairment, most articles were related to dementia (all subtypes), Alzheimer's disease, and aging. The most common article type was original scientific paper, especially cohort study. The most popular topic was the identification of protective or risk factors for cognitive impairment. Conclusion. The characteristics of articles with a high Altmetric Attention Score were somewhat different from those of articles with a high number of traditional citations. Social media had the disadvantage that it was difficult to verify the authenticity of the primary source in question, but the advantage was that it could immediately determine the trends regarding how information about that source was being shared and consumed. Therefore, it may be advisable to use Altmetric analysis in combination with traditional methods of evaluating the research articles to understand the dissemination of scientific research and to direct future research.

\section{Introduction}

As social media has evolved, academic research has spread rapidly to the public through this channel. As the life span of mankind has increased, interest in maintaining a healthy later life has increased, with a focus on cognitive function being central to this interest. Social media, therefore, is replete with information about cognitive function. Altmetrics is a new web-based set of metrics that analyzes the impact of social media platforms such as Twitter and
Facebook [1]. The Altmetric Attention Score (AAS) is a weighted score, calculated using differential weights for multiple factors depending on the amount of visibility they promote [2]. Research articles with a high AAS meant that they got more attention from social media. Traditionally, citation-based metrics such as impact factor and h-index have been used to determine the impact of articles [3]. Traditional citations take a considerable amount of time to accumulate after publication, whereas AAS is updated as soon as attention occurs online, so AAS could be used as an 
ancillary tool to evaluate the influence of the research articles, immediately.

Therefore, we would like to investigate which of the cognitive impairment-related studies received high AAS and consider the impact of these trends.

\section{Methods}

2.1. Search Engine. Altmetric Explorer (Altmetric, London, $\mathrm{UK}$ ) is a web-based application that can be used to search the following sources of research output, to yield the mostrelevant and up-to-date picture of the following types of online activity and discussion from public policy documents, blogs, mainstream media, citations data, online reference managers, research highlights, postpublication peer-review platforms, social networks, Wikipedia, Open Syllabus Project, multimedia and other online platforms, and patents [4].

We followed the methods of Kim et al. [5]. The AAS and the Altmetric donut are designed to make it easy to identify how much and what type of attention a particular research output has received [6]. The AAS is automatically calculated using an automated algorithm created by the company Altmetric, based on the weighted count of all the attention a research output has received. It is based on three main factors: volume, sources, and authors. Each color of the Altmetric donut represents a different source of attention [6].

2.2. Search Strategy. An Altmetric Explorer search was performed on May 25, 2018, for articles published in the 91 journals included in the 2015 InCites $^{\mathrm{TM}}$ Journal Citation Report ${ }^{\circledR}$ grouped under the subject categories of clinical neurology, neuroimaging, neurosciences, radiology, nuclear medicine and medical imaging, surgery, and general and internal medicine.

Two researchers (Y. J. Kim and Y. Kim) read the full papers of the top 50 articles and extracted the following information by consensus: (i) journal name, (ii) journal impact factor (IF), (iii) year of publication, (iv) article topic, (v) article type, and (vi) cognitive impairment subtype.

To clarify the AAS for the cognitive impairment field, we excluded articles that suggested composite outcomes including psychiatric disorder. If the outcomes were treated separately, the article was included in this study.

\section{Results}

Altmetric Explorer identified 43,410 articles as being referred to online. The AAS, journal name, impact factor (IF) ranking, publication year, and number of citations of the top 50 articles are summarized in Table 1. Because Altmetrics started collecting data only during the second half of 2011, the articles before 2010 were rarely listed. The number of papers on this list peaked in $2017(n=20)$. Eight articles originated from the journal Neurology followed by JAMA Internal Medicine and JAMA, each with five articles. All but one of the articles were published in journals in the highest IF quartile (Table 2). Regarding cognitive impairment subtypes, 20 articles were on dementia, 14 were on $\mathrm{Alz}$ heimer's disease, 10 were on aging, and 2 were on chronic traumatic encephalopathy (Table 3 ). Regarding article types, 40 articles were original scientific papers, 4 were related to systematic reviews and meta-analyses, 2 were related to guidelines and advisory documents, 3 were related to reviews, and 1 was related to an editorial (Table 4 ). The most common topic was risk and protective factors for cognitive impairment $(n=27)$ (Table 5$)$. In particular, as reports of cohort studies and editorials were both popular in social media, people were interested in the result that sugarsweetened beverages increased the incidence of dementia (\#3 and \#41 in Table 1) [7, 8]. However, green leafy vegetables and a Mediterranean diet had a protective effect against cognitive decline (\#5 and \#9) [9, 10]. MIND diet was also associated with decreased risk of Alzheimer's disease [11]. Glucose and vitamin D levels were associated with the risk of cognitive decline (\#17 and \#18) [12,13]. Alcohol intake and marijuana use were associated with cognitive health. Marijuana decreased perfusion of hippocampus [14]. However, there were discrepancies in opinion on alcohol consumption. In a cohort study published in 2014, excessive alcohol consumption of more than the average daily amount of $36 \mathrm{~g}$ in midlife males was associated with faster cognitive decline (\#28) [15], whereas in a study published in 2017, it was found that regular, moderate alcohol intake enhanced cognitively healthy longevity (\#21) [16]. Leisure activity and midlife cardiovascular fitness were also associated with the risk of dementia. Some studies reported that comorbid conditions such as hearing loss (\#19) [17], poor sleep (\#26) [18], and chronic pain (\#46) [19] deteriorated cognitive health. Environmental factors such as living near a major road (\#4) [20] and lead exposure (\#32) [21] affected cognitive health. Furthermore, medications such as proton pump inhibitors and anticholinergics were related to cognitive function. Over-the-counter supplement use was also effective against cognitive decline (\#35) [22]. Bilingualism (\#12, \#44, and \#47) [23-25] and marriage type (\#50) [26] could also affect cognitive health.

\section{Discussion}

Here, we summarized the top 50 articles using AAS. The mean AAS was 1171.6, and the mean of the number of citations was 109.5. Articles were published the most in 2017, and the journal "Neurology" was the most popular originated journal. Among the types of cognitive impairments, most articles were related to dementia, Alzheimer's disease, and aging. The most common article type was original scientific paper, especially cohort study. The most popular topic was the protective or risk factor.

Most of the articles were published in 2017, likely because we performed the Altmetric Explorer search on May 25,2018 . The same method used in the article written by Kim et al., co-author of this article, was used here [5]. AAS was sensitive to the latest content, and recent publications tended to receive higher AAS. For example, the Altmetric top 20 list of Parkinson's disease research published in 2017 did not include any papers that were reported to be the most 
TABle 1: Top 50 articles with the highest Altmetric Attention Scores (AASs).

\begin{tabular}{|c|c|c|c|c|c|c|}
\hline Rank & Article title & AAS & Journal name & $\begin{array}{l}\text { Impact } \\
\text { factor } \\
\text { ranking }\end{array}$ & $\begin{array}{c}\text { Date of } \\
\text { publication } \\
\text { (YYMMDD) } \\
\end{array}$ & $\begin{array}{l}\text { Number of } \\
\text { citations }\end{array}$ \\
\hline 1 & $\begin{array}{c}\text { Clinicopathological evaluation of chronic } \\
\text { traumatic encephalopathy in players of American } \\
\text { football }\end{array}$ & 3674 & $\begin{array}{l}\text { JAMA: Journal of the } \\
\text { American Medical } \\
\text { Association }\end{array}$ & Q1 & $2017-07-25$ & 170 \\
\hline 2 & Dementia prevention, intervention, and care & 3294 & The Lancet & Q1 & 2017-07-19 & 466 \\
\hline 3 & $\begin{array}{l}\text { Sugar- and artificially sweetened beverages and } \\
\text { the risks of incident stroke and dementia }\end{array}$ & 3215 & Stroke & Q1 & 2017-01-01 & 27 \\
\hline 4 & $\begin{array}{l}\text { Living near major roads and the incidence of } \\
\text { dementia, Parkinson's disease, and multiple } \\
\text { sclerosis: a population-based cohort study }\end{array}$ & 2924 & The Lancet & Q1 & 2017-01-04 & 114 \\
\hline 5 & $\begin{array}{c}\text { Nutrients and bioactives in green leafy vegetables } \\
\text { and cognitive decline: prospective study }\end{array}$ & 2538 & Neurology & Q1 & $2017-12-20$ & 15 \\
\hline 6 & $\begin{array}{l}\text { A comparison of the prevalence of dementia in } \\
\text { the United States in } 2000 \text { and } 2012\end{array}$ & 1610 & JAMA Internal Medicine & Q1 & 2016-11-21 & 158 \\
\hline 7 & $\begin{array}{c}\text { Incidence of dementia over three decades in the } \\
\text { framingham heart study }\end{array}$ & 1544 & $\begin{array}{l}\text { New England Journal of } \\
\text { Medicine }\end{array}$ & Q1 & 2016-02-11 & 277 \\
\hline 8 & $\begin{array}{c}\text { Mixed pathologies including chronic traumatic } \\
\text { encephalopathy account for dementia in retired } \\
\text { association Football (soccer) players }\end{array}$ & 1532 & Acta Neuropathologica & Q1 & 2017-02-15 & 32 \\
\hline 9 & $\begin{array}{l}\text { Mediterranean diet and age-related cognitive } \\
\text { decline: a randomized clinical trial }\end{array}$ & 1486 & JAMA Internal Medicine & Q1 & 2015-05-11 & 181 \\
\hline 10 & $\begin{array}{l}\text { Association of proton pump inhibitors with risk } \\
\text { of dementia: a pharmacoepidemiological claims } \\
\text { data analysis }\end{array}$ & 1458 & JAMA Neurology & Q1 & 2016-02-15 & 191 \\
\hline 11 & $\begin{array}{l}\text { Alzheimer's disease drug-development pipeline: } \\
\text { few candidates, frequent failures }\end{array}$ & 1281 & $\begin{array}{l}\text { Alzheimer's Research \& } \\
\text { Therapy }\end{array}$ & Q1 & 2014-07-03 & 509 \\
\hline 12 & $\begin{array}{l}\text { Bilingualism delays age at onset of dementia, } \\
\text { independent of education and immigration status }\end{array}$ & 1209 & Neurology & Q1 & 2013-01-01 & 146 \\
\hline 13 & $\begin{array}{l}\text { Circadian rest-activity pattern changes in aging } \\
\text { and preclinical alzheimer disease }\end{array}$ & 1183 & JAMA Neurology & Q1 & 2018-01-29 & 19 \\
\hline 14 & $\begin{array}{l}\text { Evidence of amyloid-beta cerebral amyloid } \\
\text { angiopathy transmission through neurosurgery }\end{array}$ & 1097 & Acta Neuropathologica & Q1 & 2018-02-15 & 12 \\
\hline 15 & $\begin{array}{l}\text { MIND diet associated with reduced incidence of } \\
\text { Alzheimer's disease }\end{array}$ & 1074 & $\begin{array}{l}\text { Alzheimer's \& Dementia: } \\
\text { the Journal of the } \\
\text { Alzheimer's Association }\end{array}$ & Q1 & 2015-02-11 & 99 \\
\hline 16 & $\begin{array}{l}\text { Practice guideline update summary: mild } \\
\text { cognitive impairment: report of the guideline } \\
\text { development, dissemination, and } \\
\text { implementation subcommittee of the american } \\
\text { academy of neurology }\end{array}$ & 1038 & Neurology & Q1 & $2017-12-27$ & 86 \\
\hline 17 & Glucose levels and risk of dementia & 1020 & $\begin{array}{l}\text { New England Journal of } \\
\text { Medicine }\end{array}$ & Q1 & 2013-08-08 & 292 \\
\hline 18 & $\begin{array}{l}\text { Vitamin D and the risk of dementia and } \\
\text { alzheimer disease }\end{array}$ & 989 & Neurology & Q1 & 2014-08-05 & 151 \\
\hline 19 & Hearing loss and cognitive decline in older adults & 956 & JAMA Internal Medicine & Q1 & 2013-02-25 & 397 \\
\hline 20 & $\begin{array}{l}\text { Midlife cardiovascular fitness and dementia: a 44- } \\
\text { year longitudinal population study in women }\end{array}$ & 954 & Neurology & Q1 & 2018-03-14 & 12 \\
\hline 21 & $\begin{array}{c}\text { Alcohol intake and cognitively healthy longevity } \\
\text { in community-dwelling adults: the rancho } \\
\text { bernardo study }\end{array}$ & 950 & $\begin{array}{l}\text { Journal of Alzheimer's } \\
\text { Disease }\end{array}$ & Q2 & 2017-06-28 & 2 \\
\hline 22 & $\begin{array}{l}\text { Cumulative use of strong anticholinergics and } \\
\text { incident dementia: a prospective cohort study }\end{array}$ & 942 & JAMA Internal Medicine & Q1 & 2015-01-26 & 251 \\
\hline
\end{tabular}


TABle 1: Continued.

\begin{tabular}{|c|c|c|c|c|c|c|}
\hline Rank & Article title & AAS & Journal name & $\begin{array}{l}\text { Impact } \\
\text { factor } \\
\text { ranking }\end{array}$ & $\begin{array}{c}\text { Date of } \\
\text { publication } \\
\text { (YYMMDD) }\end{array}$ & $\begin{array}{l}\text { Number of } \\
\text { citations }\end{array}$ \\
\hline 23 & $\begin{array}{l}\text { A } 2 \text { year multidomain intervention of diet, } \\
\text { exercise, cognitive training, and vascular risk } \\
\text { monitoring versus control to prevent cognitive } \\
\text { decline in at-risk elderly people (FINGER): a } \\
\text { randomised controlled trial }\end{array}$ & 939 & The Lancet & Q1 & 2015-03-11 & 604 \\
\hline 24 & $\begin{array}{l}\text { Impact of person-centred care training and } \\
\text { person-centred activities on quality of life, } \\
\text { agitation, and antipsychotic use in people with } \\
\text { dementia living in nursing homes: a cluster- } \\
\text { randomised controlled trial }\end{array}$ & 931 & PLoS Medicine & Q1 & 2018-02-06 & 13 \\
\hline 25 & $\begin{array}{l}\text { Leisure activities and the risk of dementia in the } \\
\text { elderly }\end{array}$ & 931 & $\begin{array}{l}\text { New England Journal of } \\
\text { Medicine }\end{array}$ & Q1 & 2003-06-19 & 868 \\
\hline 26 & $\begin{array}{l}\text { Poor sleep is associated with CSF biomarkers of } \\
\text { amyloid pathology in cognitively normal adults }\end{array}$ & 930 & Neurology & Q1 & 2017-07-07 & 25 \\
\hline 27 & $\begin{array}{c}\text { A qualitative impairment in face perception in } \\
\text { Alzheimer's disease: evidence from a reduced face } \\
\text { inversion effect }\end{array}$ & 903 & $\begin{array}{l}\text { Journal of Alzheimer's } \\
\text { Disease }\end{array}$ & Q2 & 2016-02-26 & 5 \\
\hline 28 & $\begin{array}{c}\text { Alcohol consumption and cognitive decline in } \\
\text { early old age }\end{array}$ & 895 & Neurology & Q1 & 2014-01-28 & 46 \\
\hline 29 & $\begin{array}{c}\text { Aerobic exercise and vascular cognitive } \\
\text { impairment }\end{array}$ & 884 & Neurology & Q1 & 2016-10-19 & 25 \\
\hline 29 & $\begin{array}{c}\text { Risk of pneumonia associated with incident } \\
\text { benzodiazepine use among community-dwelling } \\
\text { adults with alzheimer disease }\end{array}$ & 884 & $\begin{array}{l}\text { Canadian Medical } \\
\text { Association Journal }\end{array}$ & Q1 & 2017-04-10 & 16 \\
\hline 31 & $\begin{array}{l}\text { Summary of the evidence on modifiable risk } \\
\text { factors for cognitive decline and dementia: a } \\
\text { population-based perspective }\end{array}$ & 845 & $\begin{array}{l}\text { Alzheimer's \& Dementia: } \\
\text { The Journal of the } \\
\text { Alzheimer's Association }\end{array}$ & Q1 & 2015-06-06 & 248 \\
\hline 32 & $\begin{array}{c}\text { Association of childhood blood lead levels with } \\
\text { cognitive function and socioeconomic status at } \\
\text { age } 38 \text { years and with IQ change and } \\
\text { socioeconomic mobility between childhood and } \\
\text { adulthood }\end{array}$ & 835 & $\begin{array}{l}\text { JAMA: Journal of the } \\
\text { American Medical } \\
\text { Association }\end{array}$ & Q1 & 2017-03-28 & 51 \\
\hline 33 & $\begin{array}{l}\text { Slow wave sleep disruption increases } \\
\text { cerebrospinal fluid amyloid-beta levels }\end{array}$ & 832 & $\begin{array}{l}\text { Brain: A Journal of } \\
\text { Neurology }\end{array}$ & Q1 & 2017-08-01 & 53 \\
\hline 34 & $\begin{array}{l}\text { Discriminative properties of hippocampal } \\
\text { hypoperfusion in marijuana users compared to } \\
\text { healthy controls: implications for marijuana } \\
\text { administration in Alzheimer's dementia }\end{array}$ & 805 & $\begin{array}{l}\text { Journal of Alzheimer's } \\
\text { Disease }\end{array}$ & Q2 & 2016-11-24 & 3 \\
\hline 35 & $\begin{array}{l}\text { Over-the-counter supplement interventions to } \\
\text { prevent cognitive decline, mild cognitive } \\
\text { impairment, and clinical alzheimer-type } \\
\text { dementia: a systematic review }\end{array}$ & 800 & Annals of Internal Medicine & Q1 & 2017-12-19 & 12 \\
\hline 36 & $\begin{array}{l}\text { Effect of omega-3 fatty acids, lutein/Zeaxanthin, } \\
\text { or other nutrient supplementation on cognitive } \\
\text { function: The AREDS2 randomized clinical trial }\end{array}$ & 794 & $\begin{array}{l}\text { JAMA: Journal of the } \\
\text { American Medical } \\
\text { Association }\end{array}$ & Q1 & $2015-08-25$ & 56 \\
\hline 37 & $\begin{array}{l}\text { Effect of vitamin E and memantine on functional } \\
\text { decline in alzheimer disease: the TEAM-AD VA } \\
\text { cooperative randomized trial }\end{array}$ & 788 & $\begin{array}{l}\text { JAMA: Journal of the } \\
\text { American Medical } \\
\text { Association }\end{array}$ & Q1 & 2014-01-01 & 197 \\
\hline 38 & $\begin{array}{l}\text { Does cognitive training prevent cognitive } \\
\text { decline?: a systematic review }\end{array}$ & 787 & Annals of Internal Medicine & Q1 & 2017-12-19 & 14 \\
\hline 39 & $\begin{array}{l}\text { Physical exercise moderates the relationship of } \\
\text { apolipoprotein E (APOE) genotype and dementia } \\
\text { risk: a population-based study }\end{array}$ & 784 & $\begin{array}{l}\text { Journal of Alzheimer's } \\
\text { Disease }\end{array}$ & Q2 & 2016-01-01 & 7 \\
\hline
\end{tabular}


TABle 1: Continued.

\begin{tabular}{|c|c|c|c|c|c|c|}
\hline Rank & Article title & AAS & Journal name & $\begin{array}{l}\text { Impact } \\
\text { factor } \\
\text { ranking }\end{array}$ & $\begin{array}{c}\text { Date of } \\
\text { publication } \\
\text { (YYMMDD) }\end{array}$ & $\begin{array}{l}\text { Number of } \\
\text { citations }\end{array}$ \\
\hline 40 & $\begin{array}{c}\text { Physical activity interventions in preventing } \\
\text { cognitive decline and alzheimer-type dementia: a } \\
\text { systematic review }\end{array}$ & 762 & Annals of Internal Medicine & Q1 & 2017-12-19 & 23 \\
\hline 41 & $\begin{array}{l}\text { Sugar-sweetened and artificially sweetened } \\
\text { beverages in relation to stroke and dementia }\end{array}$ & 753 & Stroke & Q1 & 2017-01-01 & 2 \\
\hline 42 & $\begin{array}{c}\text { APOE DNA methylation is altered in lewy body } \\
\text { dementia }\end{array}$ & 743 & $\begin{array}{l}\text { Alzheimer's \& Dementia: } \\
\text { The Journal of the } \\
\text { Alzheimer's Association }\end{array}$ & Q1 & 2018-03-12 & 2 \\
\hline 43 & $\begin{array}{l}\text { Evaluation of the safety, tolerability, and efficacy } \\
\text { of pimavanserin versus placebo in patients with } \\
\text { Alzheimer's disease psychosis: a phase } 2, \\
\text { randomised, placebo-controlled, double-blind } \\
\text { study }\end{array}$ & 742 & Lancet Neurology & Q1 & 2018-03-01 & 18 \\
\hline 44 & Does bilingualism influence cognitive aging? & 736 & Annals of Neurology & Q1 & 2014-06-02 & 102 \\
\hline 45 & $\begin{array}{l}\text { Blood-brain barrier leakage in patients with early } \\
\text { alzheimer disease }\end{array}$ & 735 & Radiology & Q1 & 2016-05-31 & 93 \\
\hline 46 & $\begin{array}{l}\text { Association between persistent pain and memory } \\
\text { decline and dementia in a longitudinal cohort of } \\
\text { elders }\end{array}$ & 723 & JAMA Internal Medicine & Q1 & 2017-06-05 & 15 \\
\hline 47 & Bilingualism: consequences for mind and brain & 719 & Trends in Cognitive Sciences & Q1 & 2009-01-01 & 328 \\
\hline 48 & $\begin{array}{l}\text { Sugary beverage intake and preclinical } \\
\text { Alzheimer's disease in the community }\end{array}$ & 712 & $\begin{array}{l}\text { Alzheimer's \& Dementia: } \\
\text { The Journal of the } \\
\text { Alzheimer's Association }\end{array}$ & Q1 & 2017-03-05 & 5 \\
\hline 48 & $\begin{array}{l}\text { Testosterone treatment and cognitive function in } \\
\text { older men with low testosterone and age- } \\
\text { associated memory impairment }\end{array}$ & 712 & $\begin{array}{l}\text { JAMA: Journal of the } \\
\text { American Medical } \\
\text { Association }\end{array}$ & Q1 & $2017-02-21$ & 53 \\
\hline 50 & $\begin{array}{l}\text { Marriage and risk of dementia: systematic review } \\
\text { and meta-analysis of observational studies }\end{array}$ & 708 & $\begin{array}{l}\text { Journal of Neurology, } \\
\text { Neurosurgery \& Psychiatry }\end{array}$ & Q1 & $2017-10-31$ & 9 \\
\hline
\end{tabular}

TABLE 2: Journals with top 50 articles, ranked according to the AAS.

\begin{tabular}{|c|c|c|c|}
\hline Rank & Journal name & Impact factor ranking & Number of articles \\
\hline 1 & Neurology & Q1 & 8 \\
\hline 2 & JAMA Internal Medicine & Q1 & 5 \\
\hline 2 & JAMA: Journal of the American Medical Association & Q1 & 5 \\
\hline 4 & Alzheimer's \& Dementia: The Journal of the Alzheimer's Association & Q1 & 4 \\
\hline 4 & Journal of Alzheimer's Disease & Q2 & 4 \\
\hline 6 & Annals of Internal Medicine & Q1 & 3 \\
\hline 6 & New England Journal of Medicine & Q1 & 3 \\
\hline 6 & The Lancet & Q1 & 3 \\
\hline 9 & Acta Neuropathologica & Q1 & 2 \\
\hline 9 & JAMA Neurology & Q1 & 2 \\
\hline 9 & Stroke & Q1 & 2 \\
\hline 12 & Alzheimer's Research \& Therapy & Q1 & 1 \\
\hline 12 & Annals of Neurology & Q1 & 1 \\
\hline 12 & Brain: A Journal of Neurology & Q1 & 1 \\
\hline 12 & Canadian Medical Association Journal & Q1 & 1 \\
\hline 12 & Journal of Neurology, Neurosurgery \& Psychiatry & Q1 & 1 \\
\hline 12 & Lancet Neurology & Q1 & 1 \\
\hline 12 & PLoS Medicine & Q1 & 1 \\
\hline 12 & Radiology & Q1 & 1 \\
\hline 12 & Trends in Cognitive Sciences & Q1 & 1 \\
\hline
\end{tabular}

influential in 2011. Most research articles included in the list were 2016 or 2015 studies [27]. However, in our report, two articles, about leisure activities and bilingualism as protective factors, were included in the top 50 list even though they were published before 2011. Therefore, it was suggested that the influence of important articles through 
TABLE 3: Number of articles with top 50 AASs according to cognitive impairment subgroups.

\begin{tabular}{lc}
\hline Subgroup & Number of articles \\
\hline All dementia & 20 \\
Alzheimer's disease & 14 \\
Aging & 10 \\
Chronic traumatic encephalopathy & 2 \\
Mild cognitive impairment & 1 \\
Vascular cognitive impairment & 1 \\
Cerebral amyloid angiopathy & 1 \\
Lewy body dementia & 1 \\
\hline
\end{tabular}

TABLE 4: Number of articles with top 50 AASs according to article types.

\begin{tabular}{lc}
\hline Subgroup & Number of articles \\
\hline Original scientific papers & 40 \\
Randomized clinical trial & 8 \\
Cohort study & 22 \\
Cross-sectional study & 3 \\
Case-control study & 4 \\
Case series & 3 \\
Systematic reviews and meta-analyses & 4 \\
Guidelines and advisory documents & 2 \\
Reviews & 3 \\
Editorial & 1 \\
\hline
\end{tabular}

TABLE 5: Number of articles with top 50 AASs according to subject categories.

\begin{tabular}{lc}
\hline Subject category & Number of articles \\
\hline Risk factors and protective factors & 27 \\
Diet and nutrients & 9 \\
Social factor & 4 \\
Alcohol and drugs & 3 \\
Associated disease & 3 \\
Medication & 2 \\
Pollution & 2 \\
Sleep pattern & 2 \\
Global modifiable risk factors & 1 \\
Leisure activity & 1 \\
Prevention and treatment & 13 \\
Pathomechanism and brain biopsy & 5 \\
Epidemiology & 2 \\
Biomarker & 1 \\
Disease characteristics & 1 \\
Complications & 1 \\
\hline
\end{tabular}

social media might be weakened, but it did not disappear even after some time.

The Altmetric score generally reflects the interest of the lay public, not the scholar, because it measures all social media sources. In the past, academic research articles were typically the exclusive domain of scholars, but nowadays, because of the development of media, research articles are consumed by the general public as well as scholars. So far, the research article was a means of communication for researchers and the degree of citation was an important indicator for evaluating the quality of the articles. However, due to the development of social media, expertise on topics such as medicine and disease was widely publicly available and research that received public attention could be more readily supported. Nonetheless, since public and professional interests differ, citation index and social media indicators were not always in agreement. This analysis showed that social media audiences were most interested in modifiable risk factors related to cognitive impairment. Diet and nutrients, social factors, alcohol and drugs, and medications investigated in articles with high AAS were risk factors that could be changed through behavioral modification. In addition, people were also interested in treatment and prevention, and in particular, they were more concerned with nonpharmacologic management than pharmacologic management among treatment. In the absence of clear pharmacological treatment for dementia, it seemed that there was a relatively greater interest in factors that could help improve cognitive function, as well as prevention and nonpharmacological treatment. The top-ranked article also reported about chronic traumatic encephalopathy, which could be avoided if exposure to trauma was minimized.

Disease groups with higher AAS were all subtypes of dementia, Alzheimer's disease, and aging. It was also worth noting that interest in aging without dementia was high. This could be related to the higher interest in prevention than treatment. As there was no disease-modifying treatment for dementia, it seemed that there was more interest in how to maintain cognitive function in healthy elderly individuals. Indeed, even among scholars, the development of preventive methods to reduce cognitive impairment through lifestyle changes has been emphasized over treatment. The paper by Kivipelto and collaborators was a randomized controlled study investigating whether an intervention of diet, exercise, cognitive training, and vascular risk monitoring could prevent cognitive decline of normal elderly individuals. This paper, published in 2012 in The Lancet, was one of the most cited in the Altmetric top 50 article list for cognitive impairment (939 AAS, 604 citations) [28].

On the other hand, there was less interest in professional contents such as pathomechanism or biomarkers of dementia. For example, in Alzheimer's disease, amyloid and tau proteins are related to the pathomechanisms of the disease. As a result, the technology of detecting amyloid and tau protein in CSF or visualization of amyloid and tau using brain imaging has been highly studied [29]. However, none of these studies were included in the Altmetric top 50 list. These studies were not less important because of the low AAS of pathomechanisms or biomarker-related studies. Since the research that interests the public was not necessarily the most relevant and the Altmetric score based on social media is a reflection of the public's interest, it is difficult for AAS to accurately reflect the importance or quality of research. In addition, since social media lacks the ability to verify whether the information was real or fake [30], the possibility of misleading research spreading through social media could lead to a high AAS, despite lack of credibility or relevance. Therefore, it could be dangerous to evaluate the value of academic publications by AAS alone. 
Nevertheless, the world is rapidly evolving to use the web to share information rather than more traditional media, and because many journals are converting to open access, the information inherent in social media and other web platforms cannot be ignored. As an additional tool for evaluating a paper or topic, using AAS in combination with traditional methods can help better understand the impact of scientific findings.

\section{Conclusions}

We reviewed popular articles on cognitive impairment using Altmetric analysis. In the analysis, the most salient characteristics of top articles of interest were those that were most recently published, cohort studies, and those published in the journal Neurology. The protective or risk factors associated with cognitive impairment was the topic of greatest interest. In order to understand the flow of scientific research, we suggest using Altmetric analysis as an alternative tool, along with traditional tools for evaluating article impact.

\section{Data Availability}

The data used to support the findings of this study were supplied by "Advanced Search" in Altmetric Explorer (https://www.altmetric.com/explorer, Altmetric LLP, London, UK).

\section{Conflicts of Interest}

The authors declare no potential conflicts of interest with respect to the research, authorship, and/or publication of this article.

\section{Acknowledgments}

This research was supported by the Basic Science Research Program through the National Research Foundation of Korea (NRF) funded by the Ministry of Science and ICT (NRF2018R1C1B5086320) and the National Research Foundation of Korea (NRF) Grant funded by the Korean Government (NRF-2017R1C1B2011637 \& NRF-2019R1H1A1035599).

\section{References}

[1] T. J. Brigham, "An introduction to altmetrics," Medical Reference Services Quarterly, vol. 33, no. 4, pp. 438-447, 2014.

[2] A. D. Baheti and P. Bhargava, "Altmetrics: a measure of social attention toward scientific research," Current Problems in Diagnostic Radiology, vol. 46, no. 6, pp. 391-392, 2017.

[3] R. Duszak Jr., "The impact factory," Academic Radiology, vol. 23, no. 6, pp. 659-660, 2016.

[4] Altmetrics, 2018, https://www.altmetric.com/about-our-data/ our-sources/.

[5] Y. Kim, J.-E. Kim, Y. H. Kim, D. Y. Yoon, Y. J. Kim, and J. S. Bae, "Social attention and scientific articles on stroke: Altmetric analysis of top-50 articles," Clinical Neurology and Neurosurgery, vol. 183, Article ID 105386, 2019.

[6] Altmetrics, 2018, https://www.altmetric.com/about-our-data/ the-donut-and-score/.
[7] M. P. Pase, J. J. Himali, A. S. Beiser et al., "Sugar-and artificially sweetened beverages and the risks of incident stroke and dementia," Stroke, vol. 48, no. 5, pp. 1139-1146, 2017.

[8] H. Wersching, H. Gardener, and R. L. Sacco, "Sugar-sweetened and artificially sweetened beverages in relation to stroke and dementia," Stroke, vol. 48, no. 5, pp. 1129-1131, 2017.

[9] M. C. Morris, Y. Wang, L. L. Barnes, D. A. Bennett, B. Dawson-Hughes, and S. L. Booth, "Nutrients and bioactives in green leafy vegetables and cognitive decline," Neurology, vol. 90, no. 3, pp. e214-e222, 2018.

[10] C. Valls-Pedret, A. Sala-Vila, M. Serra-Mir et al., "Mediterranean diet and age-related cognitive decline," JAMA Internal Medicine, vol. 175, no. 7, pp. 1094-1103, 2015.

[11] M. C. Morris, C. C. Tangney, Y. Wang, F. M. Sacks, D. A. Bennett, and N. T. Aggarwal, "MIND diet associated with reduced incidence of Alzheimer's disease," Alzheimer's \& Dementia, vol. 11, no. 9, pp. 1007-1014, 2015.

[12] P. K. Crane, R. Walker, R. A. Hubbard et al., "Glucose levels and risk of dementia," New England Journal of Medicine, vol. 369, no. 6, pp. 540-548, 2013.

[13] T. J. Littlejohns, W. E. Henley, I. A. Lang et al., "Vitamin D and the risk of dementia and Alzheimer disease," Neurology, vol. 83, no. 10, pp. 920-928, 2014.

[14] D. G. Amen, B. Darmal, C. A. Raji et al., "Discriminative properties of hippocampal hypoperfusion in marijuana users compared to healthy controls: implications for marijuana administration in Alzheimer's dementia," Journal of Alzheimer's Disease, vol. 56, no. 1, pp. 261-273, 2017.

[15] S. Sabia, A. Elbaz, A. Britton et al., "Alcohol consumption and cognitive decline in early old age," Neurology, vol. 82, no. 4, pp. 332-339, 2014.

[16] E. L. Richard, D. Kritz-Silverstein, G. A. Laughlin, T. T. Fung, E. Barrett-Connor, and L. K. McEvoy, "Alcohol intake and cognitively healthy longevity in community-dwelling adults: the rancho bernardo study," Journal of Alzheimer's Disease, vol. 59, no. 3, pp. 803-814, 2017.

[17] F. R. Lin, K. Yaffe, J. Xia et al., "Hearing loss and cognitive decline in older adults," JAMA Internal Medicine, vol. 173, no. 4, pp. 293-299, 2013.

[18] K. E. Sprecher, R. L. Koscik, C. M. Carlsson et al., "Poor sleep is associated with CSF biomarkers of amyloid pathology in cognitively normal adults," Neurology, vol. 89, no. 5, pp. $445-453,2017$.

[19] E. L. Whitlock, L. G. Diaz-Ramirez, M. M. Glymour, W. J. Boscardin, K. E. Covinsky, and A. K. Smith, “Association between persistent pain and memory decline and dementia in a longitudinal cohort of elders," JAMA Internal Medicine, vol. 177, no. 8, pp. 1146-1153, 2017.

[20] H. Chen, J. C. Kwong, R. Copes et al., "Living near major roads and the incidence of dementia, Parkinson's disease, and multiple sclerosis: a population-based cohort study," The Lancet, vol. 389, no. 10070, pp. 718-726, 2017.

[21] A. Reuben, A. Caspi, D. W. Belsky et al., "Association of childhood blood lead levels with cognitive function and socioeconomic status at age 38 years and with IQ change and socioeconomic mobility between childhood and adulthood," JAMA, vol. 317, no. 12, pp. 1244-1251, 2017.

[22] M. Butler, V. A. Nelson, H. Davila et al., "Over-the-counter supplement interventions to prevent cognitive decline, mild cognitive impairment, and clinical alzheimer-type dementia," Annals of Internal Medicine, vol. 168, no. 1, pp. 52-62, 2018.

[23] S. Alladi, T. H. Bak, V. Duggirala et al., "Bilingualism delays age at onset of dementia, independent of education and 
immigration status," Neurology, vol. 81, no. 22, pp. 1938-1944, 2013.

[24] T. H. Bak, J. J. Nissan, M. M. Allerhand, and I. J. Deary, "Does bilingualism influence cognitive aging?" Annals of Neurology, vol. 75, no. 6, pp. 959-963, 2014.

[25] E. Bialystok, F. I. M. Craik, and G. Luk, "Bilingualism: consequences for mind and brain," Trends in Cognitive Sciences, vol. 16, no. 4, pp. 240-250, 2012.

[26] A. Sommerlad, J. Ruegger, A. Singh-Manoux, G. Lewis, and G. Livingston, "Marriage and risk of dementia: systematic review and meta-analysis of observational studies," Journal of Neurology, Neurosurgery \& Psychiatry, vol. 89, no. 3, pp. 231-238, 2018.

[27] R. Araújo, A. A. Sorensen, S. Konkiel, and B. R. Bloem, “Top altmetric scores in the Parkinson's disease literature," Journal of Parkinson's Disease, vol. 7, no. 1, pp. 81-87, 2017.

[28] T. Ngandu, J. Lehtisalo, A. Solomon et al., "A 2 year multidomain intervention of diet, exercise, cognitive training, and vascular risk monitoring versus control to prevent cognitive decline in at-risk elderly people (FINGER): a randomised controlled trial," The Lancet, vol. 385, no. 9984, pp. 2255$2263,2015$.

[29] G. B. Frisoni, M. Boccardi, F. Barkhof et al., "Strategic roadmap for an early diagnosis of Alzheimer's disease based on biomarkers," The Lancet Neurology, vol. 16, no. 8, pp. 661-676, 2017.

[30] BBC News, Massive Networks of Fake Accounts Found on Twitter, BBC News, London, UK, 2017. 